\title{
Not any type of rice performs equally to improve lactose-induced diarrhea characteristics in rats. Is amylose an antidiarrheal factor?
}

\author{
No tratamento das diarréias induzidas por lactose em ratos, nem todas as variedades de arroz agem da \\ mesma forma. Poderia ser a amilose um fator antidiarreico?
}

\author{
Ana Lia FELIPOFF ${ }^{1 \star}$, Angela ZULETA ${ }^{1}$, Maria Elena SAMBUCETTI ${ }^{1}$, Maria Esther RIO ${ }^{1,2}$
}

\begin{abstract}
The effectiveness of different types of rice in relation to their ability to accelerate diarrhea recovering was evaluated in a rat model of osmotic diarrhea (OD). Animals (90-100 g) received protein free diet until reaching up to $20 \%$ weight loss, followed by lactose rich diet (LRD) to induce osmotic diarrhea. Rats presenting osmotic diarrhea were divided into 4 groups, which received lactose rich diet for 4 days from 8 am to $8 \mathrm{pm}$, and one of three experimental products containing 6\% rice flour differing in amylose content during the night: high (HA), intermediate (IA), and low (LA). A group fed stock diet containing equivalent amount of lactose was taken as control and allowed to recover spontaneously. Amylose and viscosity ( $\mathrm{cp}$ at $25^{\circ} \mathrm{C}, 10 \mathrm{rpm}$ ) of final products were determined. Effectiveness was expressed as the ratio between percentages of normal vs. diarrheic stools during the treatment. Fecal characteristics in this rat model improved only as result of feeding high amylose content (HA) type of rice. In this experimental model of osmotic diarrhea in young rats, the antidiarrheal effects of rice were strongly dependent on the type of diet used and appear to be related to its amylose content.

Keywords: amylase; high amylose rice; rats; rice; diarrhea treatment.
\end{abstract}

\section{Resumo}

Avaliou-se a eficiência de diferentes tipos de arroz quanto a sua habilidade de acelerar a recuperação de um episódio de diarreia em um modelo de indução de diarreia osmótica (DO) em ratos. Animais (90-100 g) receberam dieta isenta de proteína até perderem 20\% do seu peso, seguida de uma dieta rica em lactose para indução de diarreia. Os ratos que apresentaram diarreia osmótica foram divididos em quatro grupos, os quais receberam uma dieta rica em lactose durante quatro dias das 8 às 20 horas e, durante a noite, receberam um dos produtos experimentais, com $6 \%$ de farinha de arroz e diferentes quantidades de amilose: alto (AA), intermediário (IA) e baixo (BA) teor de amilose. Um grupo alimentado com ração comercial foi escolhido como controle e para recuperação espontânea. Determinaram-se a amilose e a viscosidade $\left(25^{\circ} \mathrm{C}\right.$ e $\left.10 \mathrm{rpm}\right)$ dos produtos finais. A eficiência foi expressa como a razão entre as percentagens de fezes normais e fezes diarreicas durante o tratamento. Melhores características fecais deste modelo de indução de diarreia osmótica foram obtidas como resultado da alimentação com arroz com alto teor de amilose. Neste modelo experimental de indução de diarreia osmótica em ratos jovens, os efeitos antidiarreicos do arroz se mostraram dependentes do tipo de dieta aplicada e parecem estar relacionados com o teor de amilose. Palavras-chave: amilose; arroz com alto teor de amilose; ratos; arroz; tratamento de diarreia.

\section{Introduction}

Rice is one of the major food crops. There are more than 40,000 different varieties of rice worldwide; however, only a small number offer the quality acceptable to be grown commercially. These varieties can be divided into long, medium, and short grain. A limited amount of waxy rice is produced in some countries with technological objectives. The protein quality of rice ranks only below that of oats and surpasses that of whole wheat and corn. Rice is also a good source of vitamin B and fiber, but its main constituent is starch. Like other cereals, rice starch is a main energy supplier in the human diet. Two-thirds of the human population depend on rice in their diet. Rice provides about 20 percent of the total human calorie intake. Starch is not only an important nutrient, but it also affects food texture through its functional properties such as viscosity, gel formation, and swelling among others, which depend on the relative amounts of its components: amylose and amylopectine (USDA, 2005).

Different kinds of cooked rice are distinguished by cohesiveness or dryness, tenderness or hardness, whiteness or other colors, flavor or taste, appearance, and aroma (or its absence). Of these features, cohesiveness or dryness is the most important varietal characteristic: high amylose (25 to $30 \%$ ) of the starchy endosperm results in dry and fluffy kernels;

\footnotetext{
Received 12/08/2010

Accepted 28/02/2012 (004983)

${ }^{1}$ Department of Food Science and Experimental Nutrition, School of Pharmacy and Biochemistry, University of Buenos Aires - UBA, Junin 956, Buenos Aires, 1113,

Argentina, e-mail: felipoff@ffyb.uba.ar

${ }^{2}$ Consejo Nacional de Investigaciones Científicas y Técnicas - CONICET, Av. Rivadavia, 1917, CABA, República Argentina.

${ }^{*}$ Corresponding author
}

http://dx.doi.org/10.1590/S0101-20612012005000057 
intermediate amylose content (15 to $25 \%$ ) produces tender and slightly cohesive rice; low amylose content (10 to 15\%) leads to soft cohesive (aggregated) rice; and glutinous or waxy endosperm ( 0.8 to $1.3 \%$ amylose) produces highly sticky rice.

Rice water has been traditionally used for centuries as a therapy for diarrhea diseases and is still used for that purpose in some rural areas of the world. This is probably one of the reasons why rice, among other cereals, has been the most studied or tested to substitute glucose in oral rehydration solution (ORS) due to its ability to promote rehydration and shorten the duration of diarrheal episodes (MARTINEZ et al., 1996). Rice has the advantage of providing a low delivering glucose source such as starch and higher energy density than glucose at a similar osmolarity. Additionally, it is a source of small amounts of amino acids and protein, which are important in the repair of the intestinal mucosal damage induced by diarrhea process (MAULE-RODOVAN et al., 2004; AKOSA; KETIKU; OMOTADE, 2000; HOSSAIN et al., 2003). Finally, investigating the ability of rice to inhibit intestinal secretions, Macleod; Bennett and Hamilton (1995) characterized a low molecular weight substance as the active fraction.

Diarrhea remains the second leading cause of child mortality globally. Each year, about 2.5 billion cases of diarrhea occur among children under five years of age, and estimates suggest that overall incidence has remained relatively stable over the past two decades (BOSCHI-PINTO; VELEBIT; SHIBUYA, 2008). Even though more than half of these cases are in Africa and South Asia, in many countries of South America, morbidity and mortality due to diarrhea disease persisted into 1990s in spite of people access to health care services and the use of ORS. (SARTORI et al., 2008).

Although numerous pathogens can be the cause of diarrheas with varying etiologies, the most notorious is Vibrio cholera. In a meta-analysis of 13 clinical trials, adults and children with cholera presented about $30 \%$ decrease in stool output when fed rice-based ORS (GORE; FONTAINE; PIERCE, 1992). On the other hand, no difference between standard and rice-based ORS was found for non-cholera diarrhea (ESPGHAN/ESPID, 2008). A possible explanation of the inability to find differences might be related to typical characteristics of the types of rice used in those studies, which were carried out in different geographical areas around the world. This assumption is supported by the fact that none of the many studies reviewed on this subject define the type of rice used in the supporting experiences; this lack of information included the meta-analysis (FONTAINE; GORE; PIERCE, 2004) and the most recent guidelines for management of acute gastroenteritis (ESPGHAN/ESPID, 2008). Differences in the specific composition of each type of rice were not considered as determinant of its ability to improve time course of diarrhea. Consequently, the provided information was reduced to a single data: rice, or sometimes, its scientific cereal name, Oryza sativa.

Therefore, in order to increase the knowledge about the relationships between anti-diarrheal effect and rice composition, tree different types of rice were compared in an experimental model in young rats.

\section{Materials and methods}

Experimental Products: Three rice varieties corresponding to three different types differing in amylose content were studied: high amylose-RP2 (HA); intermediate amylose- Yeruá (IA), and low amylose waxy-Higokumochi (LA). Rice samples (Arrocera Argentina, Argentina) were ground in a ball milling and sieved through 80 meshes.

Rice based formulations (RBF) were prepared as previously described (ZULETA et al., 2004) using suspensions of the three different varieties of rice flour (HA, IA, or LA) plus milk powder in water solution, $6 \%$ and $3 \%(\mathrm{p} / \mathrm{p})$ : RBF-HA; RBF-IA, and RBF-LA, respectively. Defatted milk powder, fat content $1.5 \%$ (Nestlé, Argentina), was used. The suspensions were subjected to heat treatment for 20 minutes with reciprocal shaking (120 strokes/minnutes) at $90{ }^{\circ} \mathrm{C}$ in a water bath for starch gelatinization. After cooking, the formulations were allowed to cool and kept under refrigeration until needed.

Analysis of Experimental products: Proximate composition of products was analyzed according AOAC, 2000. Total amylose of the flours was determined by the method of Morrison and Laignelet (1983). The viscosity of the suspensions was measured on a micro-viscometer (Brookfield Engineering Laboratories Inc.) at room temperature, at 10, 30,50 and $100 \mathrm{rpm}$, and expressed in centipoises (SMITH, 1964). All samples were analyzed in triplicate.

Experimental model: an adaptation to young rats of the oral model developed by Wapnir (IBRAHIM; KOHN; WAPNIR, 2004) was used. In order to increase the sensitivity of the animals to osmotic diarrhea induction, protein depleted animals were used (FELIPOFF, 2002). Seventy rats of the Wistar strain were supplied by the breeding center of the School of Pharmacy and Biochemistry, University of Buenos Aires, Argentina. The National Institute of Health Guide for the care and use of Laboratory animals and the norms of the Ethics Committee for use of animals in experimental work (Exp. FFYB: 0735028/2011) were observed. The animals ( $90 \pm 10 \mathrm{~g}$ of body weight), were acclimatized and housed in individual suspended mesh cages in a temperature and humidity controlled environment under 12-hour light/dark regimen and given free access to water and Stock diet.

Preparatory period: the animals received a Protein free diet (PFD) to induce protein depletion for 7 to 8 days. The rats presenting about $20 \%$ of body weight loss were fed a Lactose-rich synthetic diet (LRD) ad libitum (45 g of lactose/100 g diet) for the following 3 to 4 days to induce an osmotic diarrhea. The composition of the PFD and the LRD is shown in Table 1. Both diets contained $3.91 \mathrm{Kcal}^{-\mathrm{g}^{-1}}$ and the necessary nutrients to meet the requirements for rats (REEVES; NIELSEN; FAHEY, 1993).

Treatment period: The rats presenting diarrhea were selected and randomly divided into 4 groups of 10 animals each (Table 2). All groups continued receiving the same LRD ad libitum from 8 am to $8 \mathrm{pm}$ for 4 days. During the night, from $8 \mathrm{pm}$ to $8 \mathrm{am}$, three groups received only $50 \mathrm{~g}$ of one of the three types of experimental products containing one of the sources of rice flour: RBF-HA, RBF-IA, or RBF-LA. A fourth control group 
(C), allowed to recover spontaneously from diarrhea, received a synthetic diet containing an equivalent amount of lactose and energy to that of the experimental products.

Body weight was measured at the beginning and end of each experimental period, and food intake was measured during the four days of treatment period. To monitory changes in the aspects of the stools, a plastic mesh lined with gauze was put below each mesh cage. The quantity, form, consistency, and color of the stools were recorded on a specially designed card. The severity of diarrhea was classified as (3+) when the stools were abundant, liquid, and yellow. Since the stools tended to be more solid and brown, the severity was classified as $(2+)$ or $(1+)$. The normal stools (-) were completely solid and brown. In order to evaluate the effect of rice treatment on the severity of diarrhea, the ratio between the percentage of normal stools vs. percentage of diarrheic stools was calculated every 24 hours during the four-day treatment period.

Table 1. Composition of Experimental Diets (g/100 g diet).

\begin{tabular}{|c|c|c|}
\hline & $\begin{array}{l}\text { Protein free diet } \\
\text { (PFD) }\end{array}$ & $\begin{array}{c}\text { Lactose-rich } \\
\text { synthetic diet (LRD) }\end{array}$ \\
\hline Potassium caseinate $^{1}$ & - & 20 \\
\hline Lactose $^{2}$ & - & 45 \\
\hline Lipids $^{3}$ & 4.5 & 4.5 \\
\hline Salts mixture ${ }^{3}$ & 5.0 & 5.0 \\
\hline Water-soluble vitamins ${ }^{3}$ & 0.25 & 0.25 \\
\hline Fat-soluble vitamins ${ }^{3}$ & 0.50 & 0.50 \\
\hline Choline $^{3}$ & 0.71 & 0.71 \\
\hline Dextrin $^{4}$ & 100 & 100 \\
\hline Energy (Kcal/g) & 3.91 & 3.91 \\
\hline
\end{tabular}

Table 2. Treatment Period - Duration: 4 days.

\begin{tabular}{ccccc}
\hline Experimental group & HA & IA & LA & Control \\
\hline $\begin{array}{c}\text { From } 8 \text { am to } 8 \text { pm } \\
\text { (ad libitum })\end{array}$ & LRD & LRD & LRD & LRD \\
From 8 pm to 8 am & $\begin{array}{c}\text { RBF-HA } \\
(50 \mathrm{~g})\end{array}$ & $\begin{array}{c}\text { RBF-IA } \\
(50 \mathrm{~g})\end{array}$ & $\begin{array}{c}\text { RBF-LA } \\
(50 \mathrm{~g})\end{array}$ & LRD \\
\end{tabular}

Rice based formulations (RBF). Rice variety: HA: high amilose; IA: intermediate amilose; LA: low amilose. LRD: Lactose-rich synthetic diet containing an equivalent amount of lactose and energy to that of experimental products.
Statistics: One-way analysis of variance was performed to determine significant differences between treatments. When the ANOVA indicated a significant treatment effect, the Tukey-Kramer, a posteriori multiple comparison test, was used to find differences between the treatments. Data were checked for normality before performing statistical analysis (Bartletts's Test). The GraphPad Software v 2.02 was used to perform statistical analyses. In Table 3 , the results are given as means \pm standard deviation (SEMs). Differences were considered significant when $\mathrm{p}<0.05$.

\section{Results}

Characteristics of the Experimental Products: The amylose content of each variety of rice was: $25 \%$ for HA, $19 \%$ for IA, and $5 \%$ for LA. The viscosity, of the respective suspensions, measured in centipoises (cp), is shown in Figure 1. When expressed in $\mathrm{cp}$ at $10 \mathrm{rpm}$, it ranges between 6.000 for HA and 3.000 for LA, but all the products reach a minimum value of 1.000 at $100 \mathrm{rpm}\left(\mathrm{HA}: \mathrm{y}=5132.3 \mathrm{e}^{-0.017 \mathrm{x}} ; \mathrm{R}^{2}=0.9124-\mathrm{IA}\right.$ : $\mathrm{y}=4311.4 \mathrm{e}^{-0.0116 \mathrm{x}} ; \mathrm{R}^{2}=0.8975-\mathrm{LA}: \mathrm{y}=2773.8 \mathrm{e}^{-0.0116 \mathrm{x}}$; $\mathrm{R}^{2}=0.8639$ ). As expected for viscous-elastic products, viscosity decreased with the increase of revolutions per minute, and so did the differences among them. In this study, comparisons were made at the point of maximal viscosity, $10 \mathrm{rpm}$.

Results of the rat model: The animals were generally in good health throughout the experiment. At the end of the preparatory period, there were no differences between the four groups of rats in relation to initial body weight, post-depletion body weight and post-diarrhea induction body weight (To), and in the severity of induced diarrhea. After the treatment with the different types of rice, no significant differences were found in final body weight (Tf) and in the dietary intake between the experimental and control groups (Table 3). Due to the similar macronutrient content of the three experimental formulas, changes in body weight between the starting point and the end of the four-day treatment were not dependent on the type of rice $(\mathrm{p}=0,445)$. The results shown in Table 1 are in agreement with those reported by Arciniegas, Cioccia And Hevia (2000) in undernourished adults or even young rats and confirmed that diarrhea per se does not have a negative effect on macronutrient absorption. The results are also in agreement with those reported by O'Donnell et al. (1972) investigating nutritional therapy of protracted diarrhea in children.

Table 3. Body weight, dietary intake, \% of depletion and severity of diarrhea in Experimental and Control Groups.

\begin{tabular}{|c|c|c|c|c|}
\hline & Controls & RP2 (HA) & Yerua (IA) & Higokumochi (LA) \\
\hline Initial body weight (g) & $93.9 \pm 2.09$ & $92.1 \pm 2.41$ & $92.7 \pm 1.33$ & $92.7 \pm 1.78$ \\
\hline Body weight depletion (\%) & $20.5 \pm 0.62$ & $20.9 \pm 1.31$ & $20.5 \pm 0.91$ & $21.8 \pm 0.59$ \\
\hline Post-diarrhoea body weight (g)(To) & $82.5 \pm 2.31$ & $85.2 \pm 2.56$ & $82.4 \pm 2.13$ & $77.8 \pm 2.24$ \\
\hline Severity of induced diarrhoea ${ }^{1}$ & $2.5 \pm 0.85$ & $2.4 \pm 0.69$ & $2.5 \pm 0.71$ & $2.5 \pm 0.22$ \\
\hline Post-treatment body weight (g)(Tf) & $84.0 \pm 2.05$ & $81.43 \pm 2.38$ & $84.3 \pm 1.87$ & $86.0 \pm 2.31$ \\
\hline Dietary intake during treatment $^{2}$ & $5.2 \pm 0.91$ & $4.90 \pm 0.13$ & $5.07 \pm 0.15$ & $4.84 \pm 0.20$ \\
\hline
\end{tabular}

Type of rice in each experimental groups: RP2 (HA): high amylose; Yerua (IA): intermediate amylose; Higokumochi (LA): Low amylose. Control group: monitor of spontaneous recovering from diarrhea. Values are means \pm SEM; $n=10$ rats each group; ${ }^{1}$ Values are means \pm SEM of three different grade of diarrhea severity: $(1+),(2+)$ or $(3+) ;{ }^{2} \mathrm{~g} / 100 \mathrm{~g}$ rat $/$ day.

No significant differences were found between groups. 


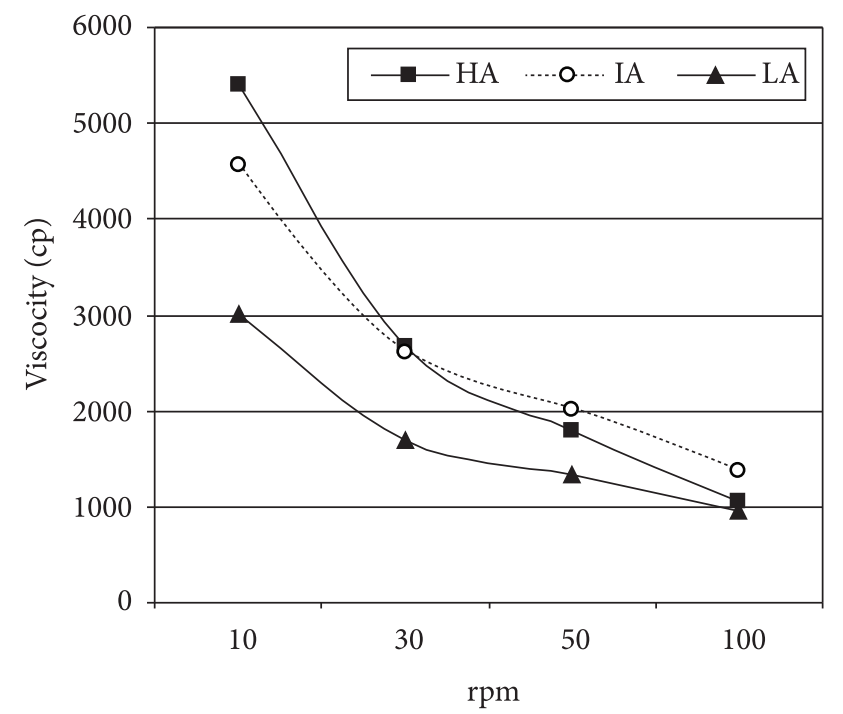

Figure 1. Viscosity of the rice suspensions measured in centipoises vs. rpm. corresponding to amylose content of each variety of rice: $25 \%$ for HA (high amylose), 19\% for IA (intermediate amylose) and 5\% for LA (low amylose).

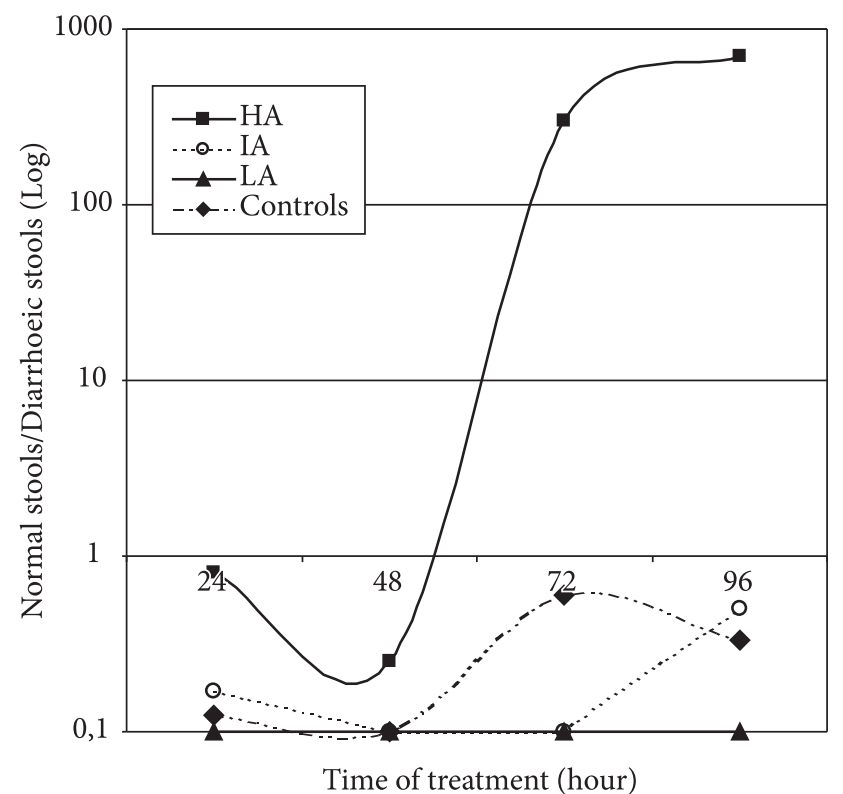

Figure 2. Ratio between percent of normal stools vs. percent of diarrhoeic stools for each experimental group during the four days of treatment. Type of rice in each experimental groups: HA: high amylose; IA: intermediate amylose; LA: Low amylose. Control group: monitor of spontaneous recovering from diarrhoea.

Time-course of diarrhea episodes: The ratio between the percentage of normal stools vs. percentage of diarrheic stools for each experimental group during the four-day treatment is shown in Figure 2. The effects of the different products on the evolution of diarrhea were strongly dependent of the variety of rice used. A clear trend to improve fecal characteristics, evaluated according to the percentage of stools with normal aspect, was only found after feeding the HA variety of rice. Changes were irrelevant in the IA group and almost absent in the LA group.

\section{Discussion}

Only $10 \%$ of episodes of diarrhea require clinical care; half of them do not need medical treatment, and $40 \%$ can be treated at home using ORS alone or a combination of ORS and drugs. The World Health Organization recommended in 2005 the use of homemade solutions to promote fluid and salt absorption (WHO, 2005). These solutions are usually based on cereals containing starch and other polymeric substances that increase the active transport of water and salt across the intestinal mucosa. The WHO recommendation resulted in considerable experimental support; several experimental and clinic studies have demonstrated different reasons providing beneficial effects for different starch substrates, either simple or in mixtures. Good examples are Maulen-Radovan et al. (2004), Sirivichayakul et al. (2000) [9], who found those effects using rice in different foods; Akosa et al. (2000), using a rice and maize mixture in studies carried out in humans; and Wingertzahn, Teichberg and Wapnir (1999) and Zuleta et al. (2004), among others, who studied products based on tapioca starch.

However, the meta-analysis performed by Gore, Fontaine and Pierce (1992) to verify the effectiveness of rice-based solutions to reduce diarrhea in children with acute non-cholera diarrhea was unable to prove the working hypothesis. After a 25-year review of the literature, a possible explanation to the variability of these results was found: none of the studies reviewed presented information about the type of rice used. This is an important fact, because significant differences between rice types have been reported, among them, the amylose content and its viscosity-enhancer effect (SAMBUCETTI; ZULETA, 1996). In previous studies of GoJT et al. (1994) on a rat model of osmotic diarrhea, it was demonstrated that viscosity-enhancing agents such as carboximethylcellulose added to WHO-ORS in perfused rat jejunum improves the effectiveness of the solution by increasing sodium and water absorption. In addition to being a low glucose releasing linear polymer, amylose plays an important role in the flow property of solutions, viscosity. Therefore, focusing on finding the reasons for the different behavior of rice varieties, the amylose content was taken as reference.

As shown in the results, the three varieties of rice used in this study differ in amylose content, its percentage range from 25 to $3 \%$; such difference is directly related to the viscosity of the products (Figure 1). In the present study, the percentage of normal feces in the groups at the end of the experiment is directly related to the viscosity. Only the rice containing the highest percentage of amylose was effective, whereas neither those containing the intermediate nor the lowest amylose content showed any effect (Figure 2). The effectiveness of the high-amylose variety of rice in terms of its capacity to increase viscosity is similar to the findings of Teichberg et al. (1999), who studied the effectiveness of an oral rehydration solution supplemented with 2.5 g.L. $\mathrm{L}^{-1}$ gum Arabic during recovery from chronic osmotic diarrhea in free-living rats. Since gum Arabic is used as viscosity enhancer (TURVILL et al., 2000 and IBRAHIN et al., 2004), it was assumed that the increased viscosity might explain, at least in part, the beneficial effects 
reported for rice when added to ORS. This hypothesis is supported by the results of this study.

Other possible explanations for the beneficial effects of higher amylose rice is the high content of amylase-resistant starch, demonstrated by Sambucetti and Zuleta (1996), when comparing different varieties of rice differing in amylose content. On the other hand, more recent studies in adults with cholera-like diarrhea episodes, it was found that substituting resistant starch for glucose in hypo-osmolar oral rehydration solution significantly improves response to ORS (RAMAKRISHNA et al., 2008). Similar results were reported in children with acute diarrhea (RAGHUPATHY et al., 2006). In both cases, the addition of resistant starch to glucose ORS significantly shortened duration of diarrhea compared with standard treatment. The presence of resistant starch in the colon results in an increase in the short-chain fatty acid concentrations, which stimulates sodium and water absorption (RAO, 2004; ELIA; CUMMINGS, 2007).

This mechanism seems to be a reasonable explanation for the lag period in diarrhea evolution found in this study as a response to the rice-based formulation prepared with high amylose rice. This is a very interesting fact because rice with high amylose content was found to be the best substrate for probiotic lactobacillus fermentation in a previous study focused on the development of improved products for shortening protracted diarrhea episodes (ZULETA et al., 2007).

Although the results obtained in this research are not conclusive concerning the identification of an antidiarrheal factor in rice, they suggest further research on this topic. What is the factor responsible for the effect present only in the short type of rice? Is it amylose? Is it resistant starch? Is it an appropriate degree of viscosity or is it a combination of factors which together provide a good substrate for lactobacillus fermentation? In any case, amylose is as a key factor because its content allows identification of the rice with ability to reduce diarrhea. Hence, this research can contribute to promote genetic modifications to produce the best rice for diarrhea therapy (JEON-SEONG et al., 2010).

\section{Conclusions}

The efficiency of rice in terms of its ability to improve diarrhea has not been supported by meta-analysis including investigations performed all over the world. The lack of information concerning the type or variety of the rice used in those studies raises doubts about whether the discrepancies between these studies were due to differences in rice composition. Based on the results of this study, it can be concluded that the working hypothesis was supported: only one of the three studied samples was able to produce the expected response in rats with osmotic diarrhea, and its antidiarrheal effect was strongly related to amylase high content. Many possible applications of a proper type or rice can emerge as a simple and economical solution to follow WHO guidelines for the treatment of diarrhea using rice-based ORS solutions (WHO, 2005).

\section{Acknowledgements}

This study was carried out with the financial support of Buenos Aires University (Integrated Project B006 UBACyT). The authors are grateful to C. Mambrin for technical assistance.

\section{References}

AKOSA, U. M.; KETIKU, A. O.; OMOTADE, O. O. The nutrient content and effectiveness of rice flour and maize flour based oral rehydration solutions. African Journal of Medicine \& Medical Sciences, v. 29, n. 2, p. 145-149, 2000.

ARCINIEGAS, E. L.; CIOCCIA, A. M.; HEVIA, P. Efecto de la diarrea inducida con lactosa sobre la disponibilidad de los macronutrientes y la función inmune en ratas nutridas y desnutridas. Archivos Latinoamericanos de Nutrición, v. 50, n. 1, p. 48-54, 2000. PMid:11048571.

BOSCHI-PINTO, C.; VELEBIT, L.; SHIBUYA, K. Estimating child mortality due to diarrhoea in developing countries. Bulletin of the World Health Organization, v. 86, p. 710-717, 2008. PMid:18797647. PMCid:2649491. http://dx.doi.org/10.2471/ BLT.07.050054

ELIA, M.; CUMMINGS, J. H. Physiological aspects of energy metabolism and gastrointestinal effects of carbohydrates. European Journal of Clinical Nutrition, v. 61, n. 1, p. 40-74, 2007. PMid:17992186. http://dx.doi.org/10.1038/sj.ejcn.1602938

EUROPEAN SOCIETY FOR PAEDIATRIC GASTROENTEROLOGY, HEPATOLOGY AND NUTRITION - ESPGHAN; EUROPEAN SOCIETY FOR PAEDIATRIC INFECTIOUS DISEASES - ESPID. Evidence-based guidelines for the management of acute gastro enteritis in children in Europe. Journal of Pediatric Gastroenterology and Nutrition, v. 46, n. 2, p. S96-S97, 2008.

FELIPOFF, A. L. Tolerancia a la lactosa en ratas en crecimiento: Efectos de las interrelaciones entre las concentraciones de proteínas y lactosa de la dieta. 2002. Tese (Doutorado)-Facultad de Farmacia y Bioquímica, Universidad de Buenos Aires, Buenos Aires, 2002.

FONTAINE, O.; GORE, S. M.; PIERCE, N. F. Rice-based oral rehydration solution for treating diarrhoea (Cochrane Review). In: COCHRANE DATABASE SYSTEMATIC REVIEWS. The Cochrane Library, Issue 3. Chichester: John Wiley \& Sons, Ltd., 2004.

GO, J. T. et al. Oral Rehydration Solutions: Increased water and sodium absorption by addition of a viscosity-enhancing agent in a rat model of chronic osmotic diarrhea. Journal of Pediatric Gastroenterology and Nutrition, v. 19, n. 4, p. 410-416, 1994. PMid:7876995. http:// dx.doi.org/10.1097/00005176-199411000-00008

GORE, S. M.; FONTAINE, O.; PIERCE, N. F. Impact of rice based oral rehydration solution on stool output and duration of diarrhoea: meta-analysis of 13 clinical trials. BMJ, v. 304, p. 287-291, 1992. PMid:1531430. PMCid:1881081. http://dx.doi.org/10.1136/ bmj.304.6822.287

HOSSAIN, M. S. et al. Rice-ORS versus glucose-ORS in management of severe cholera due to Vibrio cholerae O 139 Bengal: a randomized, controlled clinical trial. Journal of Health, Population and Nutrition, v. 21, n. 4, p. 325-331, 2003. PMid:15038587.

IBRAHIM, M. A.; KOHN, N.; WAPNIR, R. A. Proabsorptive effect of gum Arabic in isotonic solutions orally administered to rats: effect on zinc and others solutes. Journal of Nutritional Biochemistry, v. 15, n. 3, p. 185-189, 2004. PMid:15023401. http://dx.doi. org/10.1016/j.jnutbio.2003.11.003

JEON-SEONG, J. et al. Starch biosynthesis in cereal endosperm. Plant Physiology and Biochemistry, v. 48, p. 383-392, 2010. PMid:20400324. http://dx.doi.org/10.1016/j.plaphy.2010.03.006

MACLEOD, R. J.; BENNETT, H. P.; HAMILTON, J. R. Inhibition of intestinal secretion by rice. The Lancet, v. 346, p. 90-92, 1995. http:// dx.doi.org/10.1016/S0140-6736(95)92115-X 
MARTINEZ. H. et al. Selection of culturally sound home fluid management of infantile diarrhea in rural Mexico. Food and Nutrition Bulletin, v. 17, n. 2, p. 120-128, 1996.

MAULEN-RADOVAN, I. et al. Safety and efficacy of a premixed, rice.based oral rehydration solution. Journal of Pediatric Gastroenterology and Nutrition, v. 38, p. 159-163, 2004. PMid:14734877. http://dx.doi. org/10.1097/00005176-200402000-00011

MORRISON, W.; LAIGNELET, B. An improved procedure for determining apparent and total amylose in cereal and other starches. Journal of cereal Science, v. 1, p. 9-20, 1983. http://dx.doi. org/10.1016/S0733-5210(83)80004-6

O'DONNELL, A. et al. Alimentación de niños desnutridos con diarrea prolongada. Respuesta metabólica y nutricional. Archivos Argentinos de Pediatria, v. 70, p. 108-123, 1972. PMid:5051616.

RAGHUPATHY, P. et al. Amylase-Resistant Starch as Adjunct to Oral Rehydration Therapy in Children with Diarrhea. Journal of Pediatric Gastroenterology and Nutrition, v. 42, n. 4, p. 362-368, 2006. PMid:16641573. http://dx.doi.org/10.1097/01. mpg.0000214163.83316.41

RAMAKRISHNA, B. S. et al. A randomised controlled trial of glucose versus amylase resistant starch hypo-osmolar oral rehydration solution for adult acute dehydrating diarrhea. Plos ONE, v. 3, n. 2, p. e1587, 2008. http://dx.doi.org/10.1371/journal.pone.0001587

RAO, M. C. Oral rehydration therapy: New explanations for an old remedy. Annual Review of Physiology, v. 66, p. 385-417, 2004. PMid:14977408. http://dx.doi.org/10.1146/annurev. physiol.66.032902.134726

REEVES, P. G.; NIELSEN, F. H.; FAHEY, J. R. Purified diets for Laboratory Rodents: Final Report of the American Institute of Nutrition Ad Hoc writing Committee on the reformulation of the AIN-76 Rodent diet. Journal of Nutrition, v. 123, p. 1939-1951, 1993. PMid:8229312.

SAMBUCETTI, M. E.; ZULETA, A. Resistant starch in dietary fiber values measured by the AOAC method in different cereals. Cereal Chemistry, v. 73, n. 6, p. 759-761, 1996.

SARTORI, A. M. C. et al. Rotavirus morbidity and mortality in children in Brazil. Revista Panamericana de Salud Pública, v. 23 , n. 2 , p. $92-100,2008$. http://dx.doi.org/10.1590/S102049892008000200004

SIRIVICHAYAKUL, C. et al. Effects of rice powder salt solution and milk-rice mixture on acute watery diarrhea in young children. Southeast Asian Journal of Tropical Medicine and Public Health, v. 31, n. 2, p. 354-359, 2000. PMid:11127339.

SMITH, R. L. Viscosity of starch pastes. In: WHISTLER, R. L.; SMITH R. J.; WOLFROM, M. L. (Eds.). Methods in Carbohydrates Chemistry. Academic Press, 1964. v. 4, p. 240-241.

TEICHBERG, S. et al. Effect of gum Arabic in an oral rehydration solution on recovery from diarrhea in rats. Journal of Pediatric Gastroenterology and Nutrition, v. 29, n. 4, p. 411-417, 1999. http://dx.doi.org/10.1097/00005176-199910000-00008

TURVILL,J.L. et al. Cholera toxin-induced secretion in rats is reduced by a soluble fiber, gum arabic. Digestive Diseases and Sciences, v. 45, n. 5, p. 946-951, 2000.

UNITED STATES DEPARTMENT OF AGRICULTURE - USDA. Beaumont, Texaz: Rice quality categories. Agricultural Research Service, 2005.

WINGERTZAHN, M. A.; TEICHBERG, S.; WAPNIR, R. A. Modified starch enhances absorption and accelerated recovery in experimental diarrhea in rats. Pediatric Research, v. 45, n. 3, p. 397-402, 1999. PMid:10088661. http://dx.doi.org/10.1203/00006450-19990300000018

WORLD HEALTH ORGANIZATION. A manual for the treatment of diarrhea: For use by physicians and other senior health workers. Geneva: WHO, 2005. WHO/CAH/05.1.

ZULETA, A. et al. Fermented Milk-Starch and Milk-Inulin products as vehicles for lactic acid bacteria. Plant Food for Human Nutrition, v. 59, p. 1-6, 2004. PMid:15678724. http://dx.doi.org/10.1007/ s11130-004-0048-8

ZULETA, A. et al. Selection of Lactobacillus and fermented amilaceous subtracts for the development of de nutraceutical-foods for the treatment of diarrhea. In: CYTALCONGRESS, 9.; INTERNATIONAL SYMPOSIUM OF NEW TECHNOLOGIES, 2., 2007, Buenos Aires, Argentina. Anais... Buenos Aires, 2007. 